University of Nebraska - Lincoln

DigitalCommons@University of Nebraska - Lincoln

1976

\title{
Carbon Dioxide Concentration and Flux in a Large Agricultural Region of the Great Plains of North America
}

\author{
S. B. Verma \\ University of Nebraska - Lincoln
}

Follow this and additional works at: https://digitalcommons.unl.edu/natrespapers

Part of the Natural Resources and Conservation Commons, Natural Resources Management and Policy Commons, and the Other Environmental Sciences Commons

Verma, S. B., "Carbon Dioxide Concentration and Flux in a Large Agricultural Region of the Great Plains of North America" (1976). Papers in Natural Resources. 1188.

https://digitalcommons.unl.edu/natrespapers/1188

This Article is brought to you for free and open access by the Natural Resources, School of at DigitalCommons@University of Nebraska - Lincoln. It has been accepted for inclusion in Papers in Natural Resources by an authorized administrator of DigitalCommons@University of Nebraska - Lincoln. 


\title{
Carbon Dioxide Concentration and Flux in a Large Agricultural Region of the Great Plains of North America
}

\author{
Shashi B. Verma and Norman J. Rosenberg \\ University of Nebraska, Lincoln, Nebraska 68503
}

\begin{abstract}
Results of observations of $\mathrm{CO}_{2}$ concentration $\left[\mathrm{CO}_{2}\right]$ and flux in an area of typical agricultural land use in the east central Great Plains of North America (Mead, Nebraska) are reported. The observations were made at sufficient heights to represent an integration of $\mathrm{CO}_{2}$ fixation and release due to all types of land use in the region (pasture, alfalfa, annual crops). Minimum daytime $\left[\mathrm{CO}_{2}\right]$ ranges from about 295-300 ppm in late July to early August (the time of apparent maximum photosynthetic activity) to $328-332 \mathrm{ppm}$ in winter. The shape of the annual $\mathrm{CO}_{2}$ concentration cycle at Mead is described and compared with those for Mauna Loa, Hawaii, and Barrow, Alaska. Peak daytime flux of $\mathrm{CO}_{2}\left(\right.$ in $\mathrm{g} \times 10^{-7}$ $\mathrm{cm}^{-2} \mathrm{~s}^{-1}$ ) from the atmosphere to the ground varied from about 0.5 in early June to $1.5-2.0$ in late July to carly August and 0.5 in late September. The net daily $\mathrm{CO}_{2}$ flux (in grams per square meter), calculated from the downward daytime and upward nocturnal fluxes, is about 10-12 in early June, 18-20 in early August (maximum), 6-10 in September, and 1-5 in early October.
\end{abstract}

\section{INTRODUCTION}

Carbon dioxide is produced in great quantities in industrial and other combustion processes. Current estimates indicate that the global $\mathrm{CO}_{2}$ concentration is increasing by about $0.7-0.8 \mathrm{ppm} / \mathrm{yr}$ [Pales and Keeling, 1965; Bolin and Bischof, 1970; Newell and Dopplick, 1970; Cramer and Myers, 1972; Machia, 1972; Goldman, 1974]. This rate of increase is only about one third to one half the estimated input from industrial and other combustion sources [Keeling, 1970; Pales and Keeling. 1965].

Causes and effects of the increase are not fully understood. Landsberg [1970] points out that there are serious gaps in our quantitative knowledge of $\mathrm{CO}_{2}$ sources, whether of volcanic, fossil fuel, respiration, or organic decay origin. Sawyer [1971] emphasized that to estimate future trends in global $\mathrm{CO}_{2}$ concentration will require more knowledge than is currently available on how natural carbon is distributed between various reservoirs in the air, oceans, and vegetation and how the balance between them is achieved and maintained.

Analysis of oceanic consumption rates [Keeling, 1970] suggests that the shallow layers of ocean surface waters in good contact with the atmosphere can hold less than $10 \%$ of the fossil fuel $\mathrm{CO}_{2}$ which has been extracted from the atmosphere, and therefore, $\ldots$ the principal sink for $\mathrm{CO}_{2}$ must lie in the deep ocean or not be oceanic at all.'

Plant physiological studies, on the other hand, have shown conclusively that for many cultivated crops, net photosynthesis increases with increasing $\mathrm{CO}_{2}$ concentration of the ambient air [Rosenberg, 1974]. The rates of photosynthetic fixation by terrestrial plants may already have increased in response to the increased $\mathrm{CO}_{2}$ concentration, although we have no direct way of proving this effect. Greater photosynthetic capture of $\mathrm{CO}_{2}$ may also lead to increased rates of respiration and decay. Thus it appears likely that a major effect of the increased global $\mathrm{CO}_{2}$ concentration is an increased vegetative biomass and quantitatively greater $\mathrm{CO}_{2}$ exchange.

The shape of the annual and diurnal $\mathrm{CO}_{2}$ concentration curves are known for a few locations remote from major sources and sinks [e.g., Pales and Keeling, 1965]. There are some data available describing the influence of industrial con-

Copyright $\odot 1976$ by the American Geophysical Union. centrations in or near cities [Clark, 1969]. There are little data, however, on the natural patterns of $\left[\mathrm{CO}_{2}\right]$ in agricultural and forested regions where the strongest sinks for $\mathrm{CO}_{2}$ exist. Some $\mathrm{CO}_{2}$ concentration and gradient measurements made at elevations very close to various crop canopies are available [e.g., Brown and Rosenberg. 1970; Allen, 1971; Georgiyeuskiy and Khalikova, 1971; Pearman and Garratt, 1973]. These results are limited to individual crops and fields of small size.

There is a need for experimental data on the source and sink strengths which terrestrial vegetated surfaces exert for itmospheric $\mathrm{CO}_{2}$ and the buffering effect of these surfaces on global concentration. Such data are needed to begin a more systematic quantification of the component parts of the carbon cycle. In view of this, an organized program of observation has been developed at a well-instrumented rural site. Mcasurements were made at elevations (5.6-16 $\mathrm{m}$ above ground) such that the $\mathrm{CO}_{2}$ fluxes calculated should represent an integration of the region generally, rather than of the field in which the instrument mast stands.

\section{Experimental Methods}

Here we report measurements of $\mathrm{CO}$, concentration and flux rates made during the period September 1972 to December 1973 at the University of Nebraska Agricultural Meteorology Laboratory located near Mead, Nebraska $\left(41^{\circ} 09^{\prime} \mathrm{N} ; 96^{\circ} 30^{\prime} \mathrm{W}\right.$; altitude $354 \mathrm{~m}$ above $\left.\mathrm{msl}\right)$. The region in which the station is located is of flat to moderately rolling topography. A general map of land use within a $50-\mathrm{km}$ radius is given in Figure 1. Soil textures in the vicinity vary from silty clay loam on the uplands to sandy loam in terraces of a nearby valley which is one of the ancient courses of the Platte River. Within a radius of $3-4 \mathrm{~km}$ the land is farmed largely to maize, sorghum, alfalfa, and soybeans. Consequently, depending upon season, the land may be bare, in crop, or in stubble. Some of the sandier land remains in pasture grass throughout the year.

Profiles of carbon dioxide concentration, mean wind speed, and air temperature were measured simultaneously at various elevations between 2 and $16 \mathrm{~m}$. Wind speed was measured with Casella-Sheppard type cup anemometers. Air temperature was measured with a set of shielded, unaspirated differential copper constantan thermocouples. Concurrent measurements of wind direction and incident solar radiation were also made. 


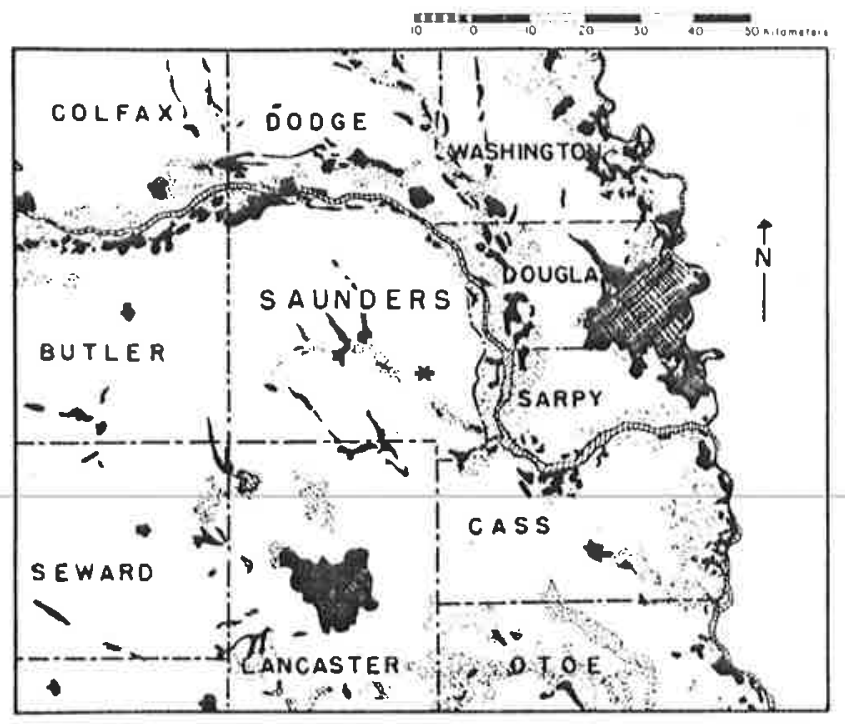

Dics: URBAN AREA

AGRICULTURE - PRIMARILY FARM CROPS, SOME FORAGE CROPS AND PASTURE.

RANGELAND - PRIMARILY NATURAL CRASSES, SOME IMPROVED PASTURE AND FORAGE CROPS.

\section{2.] FOREST - MORE THAN 10\% TREE COVER. \\ WDIDI WATER - PREDOMINANTLY OR PERSISTENTLY WATER COVERED.}

\section{* Univ. Of nebraska agric. meteorology lab. at mead}

Fig. 1. A general land use map of the region around the University of Nebraska Agricultural Meteorology Laboratory all Meild $\left(41^{\circ} 09^{\prime} \mathrm{N}, 96^{\circ} 30^{\prime} \mathrm{W}\right.$; altitude $354 \mathrm{~m}$ above $\left.\mathrm{msl}\right)$.

$\mathrm{CO}_{2}$ sampling and analysis system. A 19.2-m meteorological lower at Mead, Nebraska, is equipped with sampling intakes through which air is drawn into a laboratory building about $60 \mathrm{~m}$ away for measurement of $\mathrm{CO}_{2}$ concentration and gradients. The system has the capacity to sample air at eight locations or elevations. Individual diaphragm pumps, located near the tower (but external to the laboratory), are used for each sample line. These pumps draw air under vacuum and move it into and through the laboratory under positive pressure. The analyzers themselves are purged under a slight positive pressure with $\mathrm{CO}_{2}$ - ree $\mathrm{N}_{2}$ gas.

The simple lines terminate in the laboratory building at individual rolumeters where flow rate into the mixing chambers is controlled. Air from each separate level is continuously mixed in 7.5-1 cylinders so as to smooth out the rapid fluctuation in $\mathrm{CO}_{2}$ concentration. Periodically (usually every 15 min), air samples are drawn in sequence from the mixing cylinders through the infrared gas analyzers (IRGA). Air from the highest elevation samples (say level 1 ) is passed through a Beckman IRGA model 315A to determine the absolute concentration of $\mathrm{CO}_{2}$. Then air from the same source (level $\mathrm{I}$ ) is passed through one side of a Beckman IRGA model $315 B$, used as a differential analyzer, for comparison with air originating at the next lowest level (level 2). The concentration difference between two samples is determined in this way. In the next step, air from level 3 is drawn through the differential analyzer replacing the sample from level 1. Then the conentration dillerence between levels 2 and 3 is determined. This process is repealed until all necessary comparisons are made.

A system has been developed to permit automatic hourl: calibration of both IRGA's. Analyzer output datal during culibration runs are also recorded by the data logging system. Calibration is done in the following way. Once each hour an upsciale standard gas of known $\mathrm{CO}_{2}$ concentration is passed through the absolute IRGA, and the analyzer response is recorded. Then a downscale gas is substituted. At the simnc lime a single standard gas is passed through both sides of the differential IRGA. Zero concentration should be indicaled by the IRGA when this is done. The response, whether zero or not, is recorded. Then two different standard gases of known concentrations (dillering by a suitable working range) atte passed through the two chambers of the differential IRGA 10 record an upscale response. With the IRGA responses measured and recorded during a calibration cyck the drift of the analyzers can be monitored, and the field observations call be adjusted for changing IRGA calibrations, if any'

A comparison of standard gases of the same nominal concentration, but supplied by different manufacturers, convinced us ol the need for an independent calibration of our standard gases. Our primary standard gases were calibrated by the Air Resources Laboratory of NOAA in Boulder, Colorado. The calibrations, based on 59 manometric standards (C, D. Keeling, personal communication, 1975), were alccurale to $\pm 0.3-0.5 \mathrm{ppm}$. Our secondary standards were calibratci against these primary gases by differential gas analysis. The secondary standards were used in the automatic calibration al both analyzers.

It was lound that even small pressure differences between the reference and sample sides of the differential IRC $i A$ resulted in measurable imbalances and that the error wils increased with increasing concentration of $\mathrm{CO}_{2}$ in the sirnple gals. Concentration difference errors of the order of 1 ppom were possible. This situation was improved by use ol precise pressure regulation devices and flowmeters. It is now possible to maintain the pressure differences between the analyzer lubes at $0 \pm 1.0 \mathrm{mbar}$. These pressure differences are monitored periodically with a water manometer to detect any failures in pressure regulation.

The absorption bands of $\mathrm{CO}_{2}$ and $\mathrm{H}_{2} \mathrm{O}$ overlap. In order to prevent interference from water vapor a set of optical filters (manufactured by Grubb Parsons and Co. Lid., Newcastle upon Tyne, England) is incorporated into the path ol' the infrared radiation stream. These filters transmit only radiation in the $3.8-105.7-\mu \mathrm{m}$ wavelength band so that the main waler vapor absorplion bands are removed. Spectral transmittance of these filters is given by Janac [1971].

Temperatures of the gas samples entering the analyzer cells are monitored (using copper constantan thermocouples embedded in the flow lines) during both data and calibration cycles so that corrections can be made for any significant difference in the temperature of field air samples and laboratory gases.

Data recording. All meteorological measurements wert made on either a 7- or a 15-min cycle. Data were logged on punch lape with an automatic digital data logging systern. Raw data were converted from the digitized emf or counu record of individual sensors into parametric forms by corn. puter. All data reported in this paper have been averaged ovet half-hour periods. 
Theoretical Considerations

The exchange of $\mathrm{CO}_{2}$ is a turbulent transfer process. Vertical flux of $\mathrm{CO}_{2}, F_{c}\left(\mathrm{~g} \mathrm{~cm}^{-2} \mathrm{~s}^{-1}\right)$, is given by

$$
F_{c}=f K_{c} \frac{\partial c}{\partial z}
$$

where $K_{\mathrm{c}}\left(\mathrm{cm}^{2} \mathrm{~s}^{-1}\right)$ is the exchange coefficient for $\mathrm{CO}_{2}, \partial c / \partial z$ (ppm $\mathrm{cm}^{-1}$ ) the gradient of $\mathrm{CO}_{2}$, and $f$ the conversion factor for $\mathrm{CO}_{2}$ from parts per million to specific weight. The exchange coefficient for $\mathrm{CO}_{2}\left(K_{c}\right)$ is assumed to be equal to the exchange coefficient for water vapor $\left(K_{w}\right)$. Therefore (1) can be written as

$$
F_{c}=f K_{w} \frac{\partial c}{\partial z}=f K_{m}\left(\frac{K_{w}}{K_{m}}\right) \frac{\partial c}{\partial z}
$$

The exchange coefficient for momentum is given by

$$
K_{m}=\frac{\tau / \rho}{(\partial U / \partial z)}=\frac{u_{*}{ }^{2}}{(\partial U / \partial z)}=k^{2} z^{2}\left(\phi_{m}{ }^{-2}\right)\left(\frac{\partial U}{\partial z}\right)
$$

where $T$ is shear stress, $\rho$ is air density, $\partial U / \partial z$ is wind speed gradient equal to $\left(u_{*} / k z\right) \phi_{m}, u_{*}$ is friction velocity equal to $(\tau / \mu)^{1 / 2}, \phi_{m}$ is nondimensional wind shear or diabatic correction factor for the log-law wind profile, $k$ is von Kármán's constant, and $z$ is distance measured in vertical direction.

Combining (2) and (3) results in

$$
F_{c}=\int k^{2} z^{2}\left(\phi_{m}{ }^{-2}\right)\left(\frac{\partial U}{\partial z}\right)\left(\frac{\partial c}{\partial z}\right)\left(\frac{K_{\mathrm{ut}}}{K_{m}}\right)
$$

Under adiabalic conditions, log-law considerations (i.e., $\phi_{m}$ =1) provide good accuracy in predicling momentum transfer. The exchange coefticient for water vapor $K_{w}$ (and sensible heat $K_{n}$ ) is assumed to be equal to that of momentum $K_{m}$. In nature, however, adiabalic or neutral conditions are seldom realized, and the above assumplions (i.e., $\phi_{m}=1$ and $K_{w} / K_{m}$

$\left.=K_{h} / K_{m}=1\right)$ may lead to significant errors.

Both $\phi_{m}$ and $K_{w} / K_{m}$ (or $K_{h} / K_{m}$ ) have been found to vary with atmospheric thermal stability. Stability is usually expressed in terms of the Richardson number $(R i)$ defined as $R i=g(\partial \theta / \partial z) \theta^{-1}(\partial U / \partial z)^{-2}$, where $\theta$ is the potential temperature, $g$ is the acceleration due to gravity, and $\partial U / \partial z$ and $\partial \theta / \partial z$ are the gradients, of wind speed and potential temperature.

Stability correction formulas have been developed in recent micrometeorological investigations. Those of Pruitl et al. [1973] are used in this study.

Model of Pruill, Morgan, and Lourence (PML). 1973.

$$
\begin{aligned}
\phi_{m}= & (1-16 R i)^{-1 / 3} \text { for unstable stratification and }(1+ \\
& 16 R i)^{1 / 3} \text { for stable stratification; } \\
K_{w} / K_{m}= & 1.13(1-60 R i)^{0.074} \text { for unstable stratification and } \\
& 1.13(1+95 R i)^{-0.11} \text { for stable stratification; } \\
k= & 0.42 .
\end{aligned}
$$

This model has been tested over an oat field against two other independent methods (namely, the lysimetric and energy balance methods) for measuring $\mathrm{CO}_{2}$ flux. Results agreed within $10-20 \%$ on a short-period basis and within $5-10 \%$ on a daily basis (for details see Verma and Rosenberg [1975a]). For some periods, when daytime stability (advective inversions) were observed, the fluxes were computed assuming $\phi_{m}=1$ and $K_{w} / K_{m}=1$.

Gradients (or derivatives with respect to height) of various profiles $(c, T$, and $U$ ) were evaluated using finite differences in the manner suggested by Panofsky [1965]. If $\Psi$ is a profile variable, then the gradient is given by

$$
\frac{\partial \Psi}{\partial z}=\frac{\Psi_{2}}{\left(z_{1} z_{2}\right)^{1 / 2}} \frac{-\Psi_{1}}{\ln \left(z_{2} / z_{1}\right)}
$$

where $z_{1}$ and $z_{2}$ are the heights above the ground. This alpproximation is, of course, rigorous for logarilhmic profiles. Using this approximation, (2) becomes

$$
F_{c}=f k^{2} \frac{\left(U_{2}-U_{1}\right)\left(c_{2}-c_{1}\right)}{\left(\ln z_{2} / z_{1}\right)^{2}}\left(\frac{K_{w}}{K_{m}}\right)\left(\phi_{m}{ }^{-2}\right)
$$

\section{Results and Discussions}

Diurnal course of $\left[\mathrm{CO}_{2}\right]$. Figure 2 shows a typical diumal course of $\left[\mathrm{CO}_{2}\right]$ measured at $16 \mathrm{~m}$ above the ground. Inmediately after sunrise, with the onset of photosynthesis, there occurs a sharp drawdown in $\left[\mathrm{CO}_{2}\right]$. Concentration Jevel:i ulf between about 0800-0900 hours (solar time) with only shight change until 1600-1700 hours. Later, as phoțosynthesis ceases, a buildup occurs as the result of respiration from the plant community. Verma and Rosenberg [1975b] presented [CO.] data measured at various elevations ranging from $0.51016 \mathrm{~m}$ above the ground. The diurnal variation in $\left[\mathrm{CO}_{2}\right]$ is considerably greater at an elevation just above the crop canopy (e.g., $0.5 \mathrm{~m}$ ) than it is at an elevation removed from the canopy (e.g., $16 \mathrm{~m}$ ). Typically, the amplitude of diurnal $\left[\mathrm{CO}_{2}\right]$ cycles at $0.5 \mathrm{~m}$ is $2-4$ times that at $16 \mathrm{~m}$. $\left[\mathrm{CO}_{2}\right]$ at night ranges quitc widely and may reach $450-500 \mathrm{ppm}$ at $0.5 \mathrm{~m}$ and $350-400 \mathrm{ppm}$ at $16 \mathrm{~m}$, especially on calm nights. The diurnal pattern of $\left[\mathrm{CO}_{2}\right]$ and the day-to-day variation is a resultant of the imen. sity of photosynthesis, which is controlled by ambient light intensity and by wind speed conditions.

Annual course of $\left[\mathrm{CO}_{2}\right]$. Figure 3 shows the variation in the diurnal course of $\left[\mathrm{CO}_{2}\right]$ for selected days in the period JuneJanuary. The daytime $\left[\mathrm{CO}_{2}\right]$ ranges from a minimum of about 295-300 ppm which occurs during late July and carly August to a maximum of about $328-332 \mathrm{ppm}$ during the winter months. The amplitude of the diurnal $\left[\mathrm{CO}_{2}\right]$ cycle varies greatly as the seasons change. The daily amplitude ranges from 20-50 ppm during June, July, and August, from 10-20 $\mathrm{ppm}$ during September and October, and from $0.5-2 \mathrm{ppm}$ during the period from November to January.

In curves of diurnal $\left[\mathrm{CO}_{2}\right]$ patterns presented in Figure 3 we note that daytime $\left[\mathrm{CO}_{2}\right]$ is fairly constant during the period $1000-1600$ hours. The nighttime concentrations vary quite widely, however, depending upon the thermal stratificilion and wind speed. Mean daily daytime concentration was obtained by averaging $\left[\mathrm{CO}_{2}\right]$ measured between 0010 and 0016 hours. Plots of these daytime means and of 24-hour meins of $\left[\mathrm{CO}_{2}\right]$ measured during September 1972 to January 1973 and June-December 1973 are shown for each day of measurement in Figure 4.

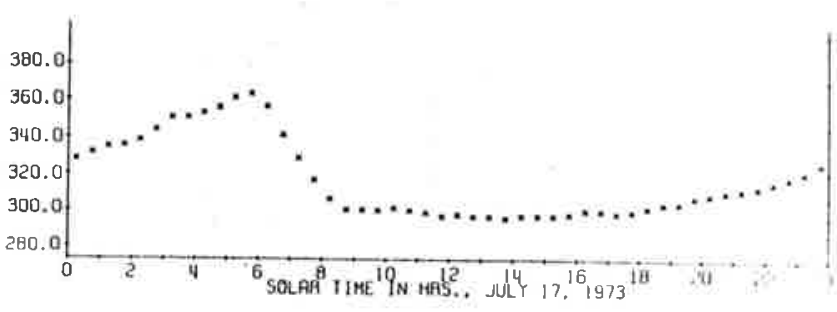

Fig. 2. Typical diurnal pattern of $\mathrm{CO}_{2}$ concentration at $16 \mathrm{~m}$ above ground during the growing season at Mead, Nebraskid. 


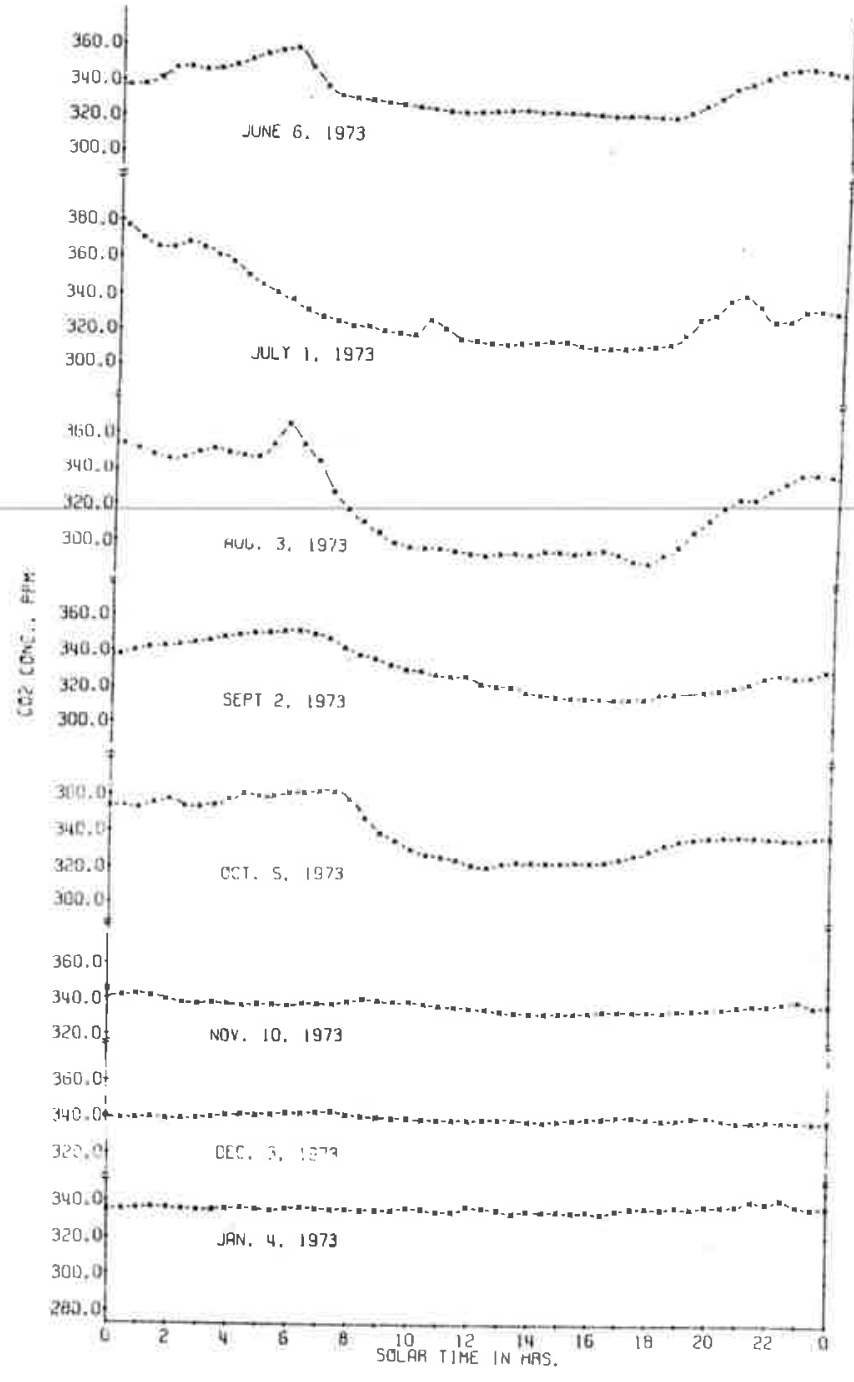

Fig. 3. The diurnal patterns of $\mathrm{CO}_{2}$ concentration at $16 \mathrm{~m}$ above ground at various times of year at Mead, Nebraska.
Seasonal influences on $\left[\mathrm{CO}_{2}\right]$ are evident. In late spring and early summer, mean daytime and 24-hour averages are about 320 and 330. respectively. As crops in the region begin to grow rapidly, $\left[\mathrm{CO}_{2}\right]$ decreases, reaching a minimum at about the end of July or beginning of A ugust. Mean daytime $\left[\mathrm{CO}_{2}\right]$ is about 295-298 ppm at this time of year when photosynthetic fixition rates are most rapid (see below). Later in August, $\left[\mathrm{CO}_{2}\right]$ begins to increase as photosynthetic activity of vegetation in the region declines. By the middle of September most of the vegetation is maturing and leaves of many crops entel senescence. Mean daytime $\left[\mathrm{CO}_{2}\right]$ increases to about 315-325 ppon. During winter months, mean daytime [CO.] ranges fiom about 325 to $335 \mathrm{ppm}$. The points in Figure 4 were fitted bs curvilinear regression (second-degree polynomial) to depict the annual cycle of the mean daytime and 24-hour-averaged $\left[\mathrm{CO}_{2}\right]$. It should also be noted in Figure 4 that the concentrations observed in the fall and winter months of 1972 and 1973 are in close agreement.

Plots of the monthly averages of the mean daytime and 24. hour $\left[\mathrm{CO}_{2}\right]$ at Mead are presented in Figure 5. For it qualitative comparison, annual cycles of $\left[\mathrm{CO}_{2}\right]$ observed at Mauna Loa, Huwaii (C. D. Keeling, personal communication, 1975), and Barrow, Alaska [Kelley, 1968] are also plolled in this figure. Levels of $\left[\mathrm{CO}_{2}\right]$ at Barrow are lower than those at Mauna Loa and Mead. Barrow data were measured 10 years tarlier, and this may account for a difference of aboul 7- $\psi$ ppm, on the average.

A substantially greater buildup of nocturna! $\left[\mathrm{CO}_{2}\right]$ is evident in the 24-hour average data at Mead, as compared to Mauna Loa and Barrow. The $\left[\mathrm{CO}_{3}\right]$ minimum observed during the growing season at Mead is sharper than that at Barrow and Mauna Loa. The vigorous photosynthetic activity in the region may, possibly, result in this substantial drawdown in $\left[\mathrm{CO}_{2}\right]$. The amplitude of annual $\left[\mathrm{CO}_{2}\right]$ cycle observed at Mauna Loa, biologically a relatively inert location, is smaller than the amplitudes observed at Mead and Barrow. Also the annual minimum occurs later in the year at Mauna Loa than at Mead and Barrow. Bolin and Keeling [1963] have suggested that this lag may be due to latitudinal effects.

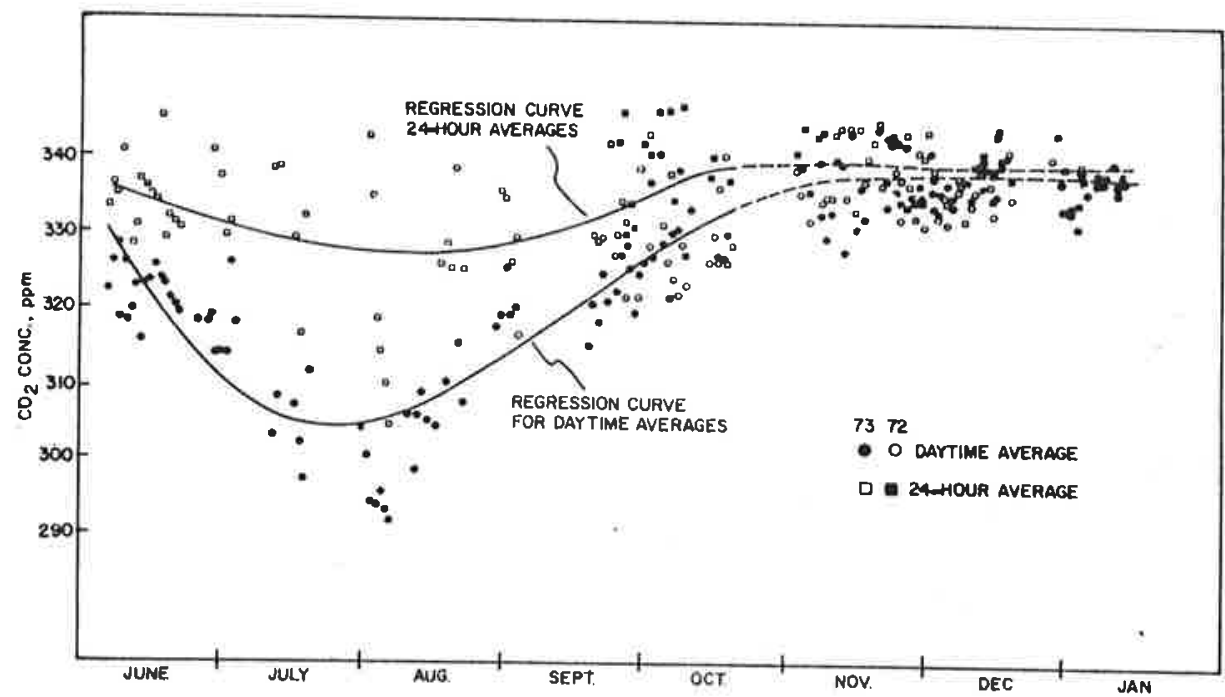

Fig. 4. Daytime and 24-hour means of $\mathrm{CO}_{2}$ concentration at $16 \mathrm{~m}$ above ground during the periods September 1972 to January 1973 and June-December 1973 at Mead, Nebraska. The curvilinear regressions are filled to the data for only the period of the year shown by the solid lines. 
$\mathrm{CO}_{2}$ flux. Rates of $\mathrm{CO}_{2}$ flux to and away from the ground were computed from the measured profiles of $\left[\mathrm{CO}_{2}\right]$, wind speed, and air temperature. The PML stability-corrected aterodynamic method, outlined in the previous section, was used for this purpose. Measurements were made at elevations (5.6-16 $\mathrm{m}$ above ground) such that the $\mathrm{CO}_{2}$ fluxes calculated should represent an integration of the region generally, rather than of the field in which the instrument mast stands. If it is assumed that a fetch to height ratio of $200 / 1$ is required for a fully developed boundary layer in this type of area of flat to rolling topography, the sensors between 5.6 and $16 \mathrm{~m}$ should sample air conditioned within an area of about $1-$ to $3-\mathrm{km}$ radius. To avoid tower wind-shadow effects, only SE-SW winds are considered in this paper. The sign convention adopted here gives $\mathrm{CO}_{2}$ flux toward the ground as positive and away from the ground as negative.

Figure 6 shows some typical plots of $\mathrm{CO}_{2}$ fluxes meusured during the period June-October 1973. Positive fluxes of $\mathrm{CO}_{2}$ from the air above to the photosynthesizing crop occur for $11-12$ hours daily. The magnitudes of these fluxes depend, primarily, upon solar radiation, wind speed, and air temperature, Average radiation, wind speed, and air temperature for the days depicted in the figure are given in Table 1. The peak daytime fluxes (in $\mathrm{g} \times 10^{-7} \mathrm{~cm}^{-2} \mathrm{~s}^{-1}$ ) ranged from about 0.5 in early June to 1.5 or 2.0 in early August and 0.5 in late September. Negative fluxes measured over the crop at night represent the sum of the soil and crop respiration which depends primarily on the soil and air temperature.

The areas under positive and negative portions of the daily flux curves were integrated, and the results plotted in Figure 7. Lines fitted by curvilinear regression (second-degree polynomial) are shown for both daytime (positive) and nocturnal (negative) fluxes. Scatter in data is partly due to the dayto-day variability of meteorological conditions. A seasonal trend is, however, evident. In early June, daytime and nocturnal fluxes are about $15-20 \mathrm{~g} \mathrm{~m}^{-2}$ and $-310-7 \mathrm{~g} \mathrm{~m}^{-2}$, respectively. As the growing season progresses, both fluxes increase. with the daytime maximum of about $20-35 \mathrm{~g} \mathrm{~m}^{-2}$ around late

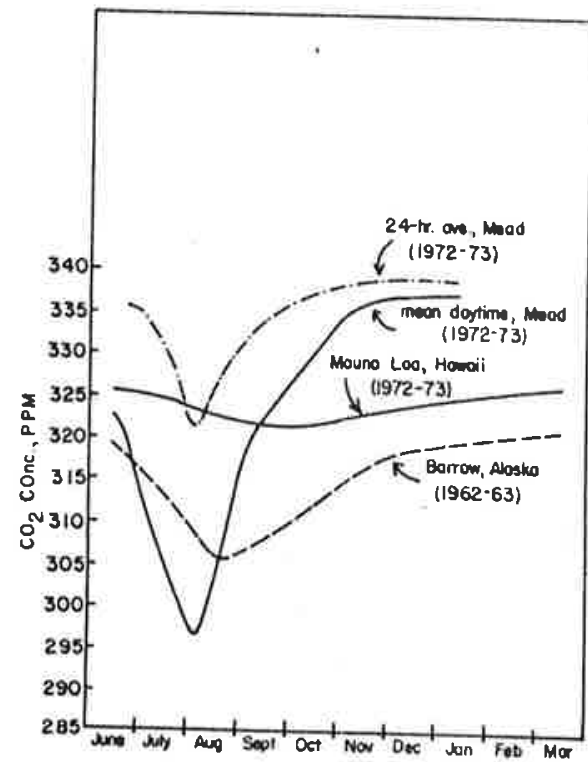

Fig. 5. A part of the annual cycle of $\mathrm{CO}_{2}$ concentration at Mead Nebraska. The lines are drawn through monthly means of the daytime and 24-hour concentrations. Comparative data for Barrow, Alaska,
and Mauna Loa, Hawaii, are also shown.

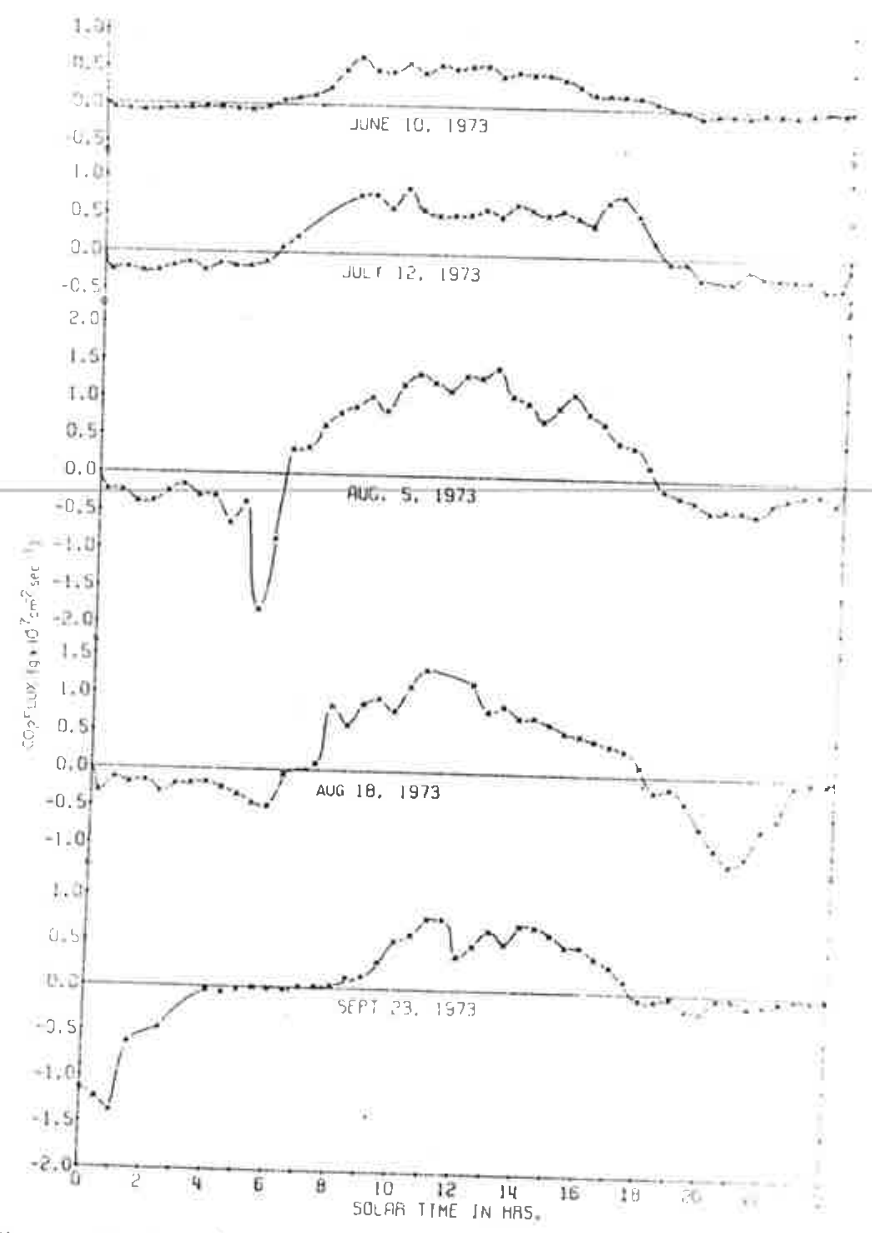

Fig. 6. Typical plots of the diurnal patterns of $\mathrm{CO}_{2}$ flux during June-October 1973 at Mead, Nebraska.

July and early August. By this time the nocturnal lluxes [evel off to a value of about -10 to $-12 \mathrm{~g} \mathrm{~m}^{-2}$. Later in the seusou, as the crops in the area start to mature and photosynthelic ativity decreases, the daytime fluxes of $\mathrm{CO}_{2}$ diminish. The regression lines suggest that during September and Octobse it slight increase in nocturnal flux occurs. If this effect is real, it may be caused by a temporary surge in respiration as plant materials senesce and die.

A curve representing the seasonal variation of net daily almospheric $\mathrm{CO}_{2}$ flux is also shown in Figure 7. Photosynthesis is supplied during daylight by downward $\mathrm{CO}_{2}$ flux from the at mosphere and upward $\mathrm{CO}_{2}$ flux from the soil and crop itseli. The upward $\mathrm{CO}_{2}$ flux at night is supplied by plant and soil respiration. Thus the difference between daytime and nighttime fluxes above the crop is a rough measure of the amount of $\mathrm{CO}_{2}$ fixed daily in the biosphere and not necessarily a direct measure of the crop photosynthesis. Net $\mathrm{CO}_{2}$ fluxes were $10-12 \mathrm{~g} \mathrm{~m}^{-2}$ in early June, $18-20 \mathrm{~g} \mathrm{~m}^{-2}$ in early August (maximum), $6-10 \mathrm{~g} \mathrm{~m}^{-2}$ in September, and $1-5 \mathrm{~g} \mathrm{~m}^{-2}$ in early Oc-
tober.

In Figure 7, peak daytime (downward) $\mathrm{CO}_{2}$ flux is shown to occur around the period late July to early August. Figures 4 and 5 show that minimum $\left[\mathrm{CO}_{2}\right]$ occurred during the same period. The results of the flux and concentration observations: are mutually supportive and suggest, strongly, that the photosynthetic activity is most intense in the east central Great Plains during late July to early August. 
TABLE 1. Solar Energy Receipts and Mean Daily Temperature and Wind Speed on Selected Days During 1973 at Mead, Nebraska

\begin{tabular}{rccc}
\hline Date & $\begin{array}{c}\text { Solar } \\
\text { Radiation, } \\
\text { Ly d }\end{array}$ & $\begin{array}{c}\text { Mean Wind Speed } \\
\text { at } 5.6 \mathrm{~m}, \\
\mathrm{~m} \mathrm{~s}^{-1}\end{array}$ & $\begin{array}{c}\text { Mean Air } \\
\text { Temperature at } \\
5.6 \mathrm{~m},{ }^{\circ} \mathrm{C}\end{array}$ \\
\hline June 9 & 715 & 5.04 & 25.6 \\
10 & 718 & 6.68 & 25.9 \\
11 & 715 & 4.76 & 26.3 \\
19 & 633 & 4.14 & 20.9 \\
30 & 506 & 3.57 & 21.2 \\
July 11 & 682 & 2.46 & 26.0 \\
12 & 712 & 4.33 & 27.3 \\
16 & 691 & 3.04 & 21.1 \\
17 & 608 & 3.96 & 23.3 \\
31 & 641 & 2.44 & 19.0 \\
Aug. 2 & 648 & 1.57 & 19.9 \\
3 & 641 & 2.48 & 22.4 \\
5 & 631 & 4.95 & 23.2 \\
6 & 439 & 4.61 & 24.4 \\
11 & 446 & 2.80 & 22.3 \\
$13^{*}$ & 586 & 3.59 & 23.1 \\
$16 \dagger$ & 593 & 3.50 & 24.2 \\
18 & 585 & 4.06 & 25.3 \\
19 & 590 & 3.31 & 26.8 \\
20 & 588 & 2.56 & 23.5 \\
22 & 514 & 4.51 & 26.5 \\
3 & 536 & 3.34 & 19.6 \\
23 & 247 & 3.73 & 16.6 \\
25 & 314 & 3.24 & 17.0 \\
2 & 401 & 2.86 & 15.8 \\
3 & 47 & 4.44 & 14.7 \\
6 & 74 & 2.88 & 13.0 \\
7 & 106 & 3.02 & 15.7 \\
Oct. & & &
\end{tabular}

*0000-0200 hours missing.

†0000-0700 hours missing.

The greatest receipts of solar radiation in eastern Nebraska occur at the time of the summer solstice, since no anomalous climatic conditions interfere [Rosenberg. 1964]. The maximum of net photosynthetic activity identified above occurs at the same time as the annual peak of air temperature [Neild et al., 1967]. The linkage is probably coincidental since it is respiration rather than photosynthesis which depends directly on temperature. More likely, the occurrence of maximum photosynthetic activity at Mead is related to the development ol' the greatest biomass. Most important, annual crops grown in the region reach their full vegetative growth by latc July ur early August.

Leilh [1965], using then available data, attempled lo mitp total worldwide carbon uptake by land plants. He considered his maps a first approximation and emphasized that detilits were still uncertain. Junge and Czeplak [1968] replotted these maps and integrated the values for each $10^{\circ}$ belt of latitude. For such a belt around $41^{\circ} \mathrm{N}$ latitude they estimate a net uptake of carbon of about $2.7 \times 10^{16} \mathrm{~g}$ during the vegctitlive period of the year. The surface area of the earth for a $10^{\circ}$ latilude belt is 2 II $R^{2} \cos \phi d \phi$, with $d \phi=0.175$ and radius $R=$ $6.366 \times 10^{8} \mathrm{~cm}$. One gram of carbon yields $3.67 \mathrm{~g} \mathrm{CO}_{2 .} . \mathrm{Ac}$ cording to Junge and Czeplak's estimates, then, the mean daily net uptake of $\mathrm{CO}_{2}$ in our latitude should be about $0.41 \times 10$ o $\mathrm{g} \mathrm{cm}^{-2} \mathrm{~s}^{-1}$ (average for the summer vegetative period). Oul ${ }^{-3-}$ timates are of the same order of magnitude, allholph somewhat higher.

Garratt and Pearman [1973] gave a value of the mean daily surface $\mathrm{CO}_{2}$ flux of $1 \times 10^{-8} \mathrm{~g} \mathrm{~cm}^{-2} \mathrm{~s}^{-1}$. This value represents the net transfer of $\mathrm{CO}_{2}$ from atmosphere to surface and should apply to a wide range of vegetation. This result was based on Woodwell and Whittaker's [1968] estimates, which range from 0.4 to $1.8 \times 10^{-6} \mathrm{~g} \mathrm{~cm}^{-2} \mathrm{~s}^{-1}$ for forests and grasslands, and Odum's [1959] estimates of 0.4 to $1.6 \times 10^{-8} \mathrm{~g} \mathrm{~cm}^{-2} \mathrm{~s}^{\prime}$ for many major types of cultivated and uncultivated crops. In some of their own measurements, Garratt and Pearman found a seasonal average value of $1.4 \times 10^{-8} \mathrm{~g} \mathrm{~cm}^{-2} \mathrm{~s}^{-1}$ for whe: 1 crop in southeast Australia. Brown and Rosenberg [1971], from dry matter sampling and flux measurements in western Nebraska, found a net $\mathrm{CO}_{2}$ accumulation rate for sugar bects of about 2.6 to $3.2 \times 10^{-4} \mathrm{~g} \mathrm{~cm}^{-2} \mathrm{~s}^{-1}$ during the period of peak photosynthetic activity.

Considering an areal average of surface $\mathrm{CO}_{2}$ flux for lengu scales upward of $1000 \mathrm{~km}$ (corresponding to the time scalcs of atmosphere surface interaction $>1-2$ days), Garratt and Pearman suggest a value close to $1 \times 10^{-8} \mathrm{~g} \mathrm{~cm}^{-2} \mathrm{~s}^{-1}$ as most appropriate. This value cannot be an underestimate, since the tropospheric vertical gradient of $\mathrm{CO}_{2}$ concentration in the northern hemisphere [Munn and Bolin, 1971] implies a large.

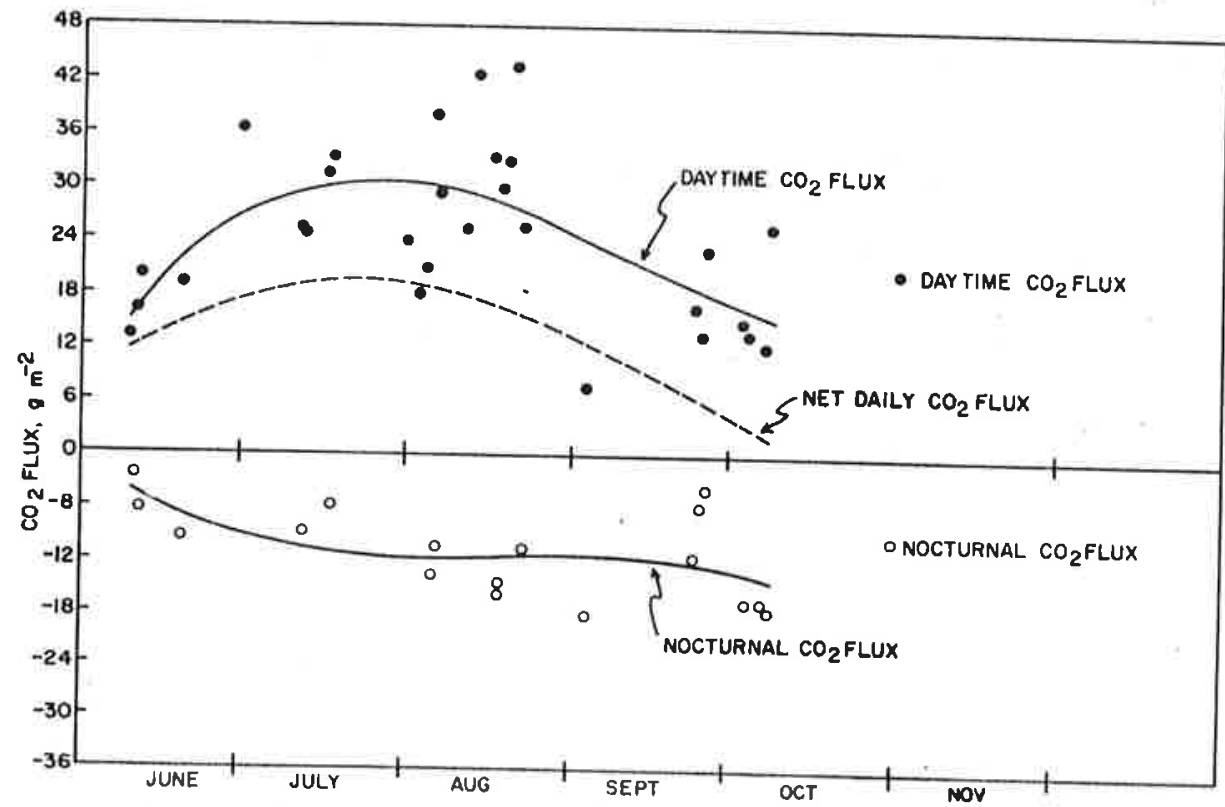

Fig. 7. The seasonal pattern of daytime, nocturnal, and net daily $\mathrm{CO}_{2}$ flux. June-October 1973 at Mead, Nebraska. 
scale $\mathrm{CO}_{2}$ flux for surface vegetation of the order of $0.5 \times 10^{-6}$ $\mathrm{g} \mathrm{cm}^{-2} \mathrm{~s}^{-1}$. Our estimates of mean daily input of $\mathrm{CO}_{2}$ (in $10^{-8} \mathrm{~g}$ $\left.\mathrm{cm}^{-2} \mathrm{~s}^{-1}\right)$ are 1.2-1.4 in early June, $2.1-2.3$ in early August (maximum), 0.70-1.2 in September, and $0.10-0.60$ in early October, values in consonance with others cited in the literature for a wide range of vegetation types.

It may be worthwhile to note that most of the large-area $\mathrm{CO}_{2}$ llux data available in the literature are based on ecological and other considerations. So far as we know, ours is the first attempt to estimate large-area $\mathrm{CO}_{2}$ flux using actual measurements of $\mathrm{CO}_{2}$ gradients and other controlling meteorological variables.

\section{SUMMARY}

Dita are presented on the cycle of carbon dioxide concentration and flux at Mead, Nebraska. Measurements were made at clevations $(5.6-16 \mathrm{~m}$ above ground) such that the $\mathrm{CO}_{2}$ fluxes calculated should represent an integration of the region generally, rather than of the field in which the instrument mast stands. Distinct seasonal variations in both concentration and hux of $\mathrm{CO}_{2}$ were ubserved.

The daytime $\left[\mathrm{CO}_{2}\right]$ ranges from about $295-300 \mathrm{ppm}$ during late July to early August to $328-332 \mathrm{ppm}$ during the winter months. The peak daytime fluxes (in $\mathrm{g} \times 10^{-7} \mathrm{~cm}^{-2} \mathrm{~s}^{-1}$ ) vary from about 0.5 in early June to 1.5 or 2.0 in late July to early August, and 0.5 in late September.

The minimum annual $\left[\mathrm{CO}_{2}\right]$ is observed around late July. $\mathrm{CO}_{2}$ flux rates reach a maximum during the same period. Together, these data suggest a distinct peak in photosynthetic activity in the region at this time. This peak, we speculate, is due to the coincidence with the achievement of maximum biomass in the annual crops of the region.

The annual cycle of $\left[\mathrm{CO}_{2}\right]$ observed at Mead is compared with that at Barrow, Alaska, and Mauna Loa, Hawaii. The minimum in $\left[\mathrm{CO}_{2}\right]$ at Mead is relatively sharp and intense compared with those at the other locations. The minimum $\left[\mathrm{CO}_{2}\right]$ at Mauna Loa lags those at Barrow and Mead by about 1-2 months.

Acknowledgments. This study was conducted with support of the Environmental Data Service, National Oceanic and Atmospheric Ad. ministration. U.S. Department of Commerce, under contract 2-35385. We would like to thank C. D. Keeling of Seripps Institution of Oceanography, La Jolla, California, for providing data on the 1972-1973 carbon dioxide concentration measured at Mauna Loa, Hawaii. Our thanks to Dale E. Sandin, James Hines, and Roberta Sandhorst, who assisted in the field observation and data computation, and to our colleagues Raoul Lemeur, Blaine L. Blad, and Maximo W. Baradas for timely help and suggestions. Published as paper 3844, Journal Series, the Nebraska Agricultural Experiment Station. The work reported was conducted under Nebraska Agricultural Experiment Station Project 20-31 and Regional Research Project 11-33.

\section{REFERENCES}

Allen, L. H., Jr., Variations in carbon dioxide concentration over an agricultural field, $\mathrm{Agr}$. Meteorol., 8, 5-24, 1971.

Bolin, B., and W. Bischof, Variations of the carbon dioxid of the atmoside content of the atmosphere in the northern hemisphere, Tellus, 22,
$431-442,1970$.

Bolin, B., and C. D. Keeling, Large-scale atmospheric mixing as deduced from the seasonal and meridional variations of carbon dioxide, J. Geophys. Res., 68, 3899-3920, 1963.

Brown, K. W., and N. J. Rosenberg, Concentration of $\mathrm{CO}_{2}$ in the air above a sugar beet field, Mon. Weather Rev., 98, 75-82, 1970.

Brown, K. W., and N. J. Rosenberg, Energy and $\mathrm{CO}_{2}$ balance of an irrigated sugar beet (Beta vulgaris) field in the great Plains,
Agron. J., 63, 207-213, 1971.
Clark, J. F., A meteorological analysis of carbon dioxide concen trations measured at a rural location, Atmos. Environ. is $375-383,1969$.

Cramer, J., and A. L. Myers, Rate of increase of atmospheric cai bon dioxide, Atmos. Environ, 6, 563-573, 1972.

Garratt, J. R., and G. I. Pearman, $\mathrm{CO}_{2}$ concentration in the atmo spheric boundary-layer over south-east Australia. Atmos. En viron., 7, 1257-1266, 1973

Georgiyevskiy, Yu. S., and R. Kh. Khalikova, Seasonal and diily variations in the $\mathrm{CO}_{2}$ content of the ground layer, $\mathrm{kv}$. A k a $\mathrm{s}$. St Atmos. Oceanic Phys., 7, 656-659, 1971.

Goldman, M. A., Carbon dioxide measurements and local wind patterns at Mauna Loa Observatory. Hawaii, $J$. Geophys. Rits.
$70,4550-4554,1974$.

Janac, J., Infra-red gas analyzers and other physical analyzers, in Plant Photosynthetic Production, Manual of Methods, edited by Z. Sestak, J. Catsky, and P. G. Jarvis, W. Junk N. V. Publishert, The Hague, 1971.

Junge, C. E., and G. Czeplak, Some aspects of the seasonal varis. tion of carbon dioxide and ozone, Tellus, 20(3), 422-434, 196 is

Keeling, C. D., Is carbon dioxide from fossil fuel changing man's environment, Proc. Amer. Phil. Soc., 114, 10-17, 1970.

Kelley, J. J., Carbon dioxide and ozone in the arctic atmospher., in Arctic Drifting Stations, pp. 155-166, coordinated by J. L. Sater, Arctic Institute of North America, Washington, L) (
1968.

Landsberg, H. E., Man-made climatic changes, Scuence, 1i, 1265-1274, 1970 .

Lieth, H., Versuch einer kartographischen Darstellung der Pro duktivitat der Pflanzendecke auf der Erde, in Geographisc.s. Taschenbuch, pp. 72-79, Franz Steiner, Wiesbaden, 1965.

Machta, L., Mauna Loa and global trends in air quality, $B_{4} l l$ Amer. Meteorol. Soc., 53, 402, 1972.

Munn, R. E, and B. Bolin, Global air pollution-Meteorologicial aspects, Atmos. Environ, 5, 363-402, 1971.

Neild, R. E., N. J. Rosenberg; and R. E. Myers, Temperature pat terns and some relations to agriculture in Nebraska, Misc. Publ 16. Nebr. Agr. Exper. Sta., Lincoln, 1967.

Newell, R. E, and T. C. Dopplick, The effect of changing $\mathrm{CO}_{2} \mathrm{con}$. centration on radiative heating rates, J. Appl. Meteorol, y. $958-959,1970$.

Odum, E. T., Fundamentals of Ecology, 2nd ed., Saunders, Philadelphia, Pa., 1959.

Pales, J. C., and C. D. Keeling, The concentration of atmospheric, carbon dioxide in Hawaii, J. Geophys. Res., 70, 6035-6076,
1965 .

Panofsky, H. A., Reanalysis of Swinbank's Kerang observations, Flux of Heat and Momentum in the Planetary Boundary Layer, pp. 66-76, Dep. of Meteorol., Pa. State Univ., University Park, 1965.

Pearman, G. I., and J. R. Garratt, Carbon dioxide measurements above a wheat crop, 1, Observations of vertical gradients and concentrations, Agr. Meteorol., 12, 13-25, 1973.

Pruitt, W. O., D. L. Morgan, and F. J. Lourence, Momentum and mass transfer in the surface boundary layer, Quart. J. Roy: Meteorol. Soc., 99, 370-386, 1973.

Rosenberg, N. J., Solar energy and sunshine in Nebraska, Nebr. Agr. Exper. Sta. Res. Bull. 213, 31 pp., 1964.

Rosenberg, N. J., Microclimate: The Biological Environumu 211-212, John Wiley, New York, 1974.

Sawyer, J. S., Possible effects of human activities on world climate, Weather, 26, 251-262, 1971.

Verma, S. B., and N. J. Rosenberg, Accuracy of lysimetric, energy balance and stability-corrected aerodynamic methods of estimating above canopy flux of $\mathrm{CO}_{2}$, Agron. J., in press, $1975 a$.

Verma, S. B., and N. J. Rosenberg, Vertical profiles of carbon dioxide concentration in stable stratifications, submitted to Agr. Meteorol., $1975 b$.

Woodwell, G. M., and R. H. Whittaker, Primary production in terrestrial ecosystems, Amer. Zool., 8, 19-30, 1969.

(Received August 14, 1974; revised June 19, 1975; accepted July 9, 1975. 